\title{
Assessment of Teachers' Nonmonetary Motivational Factors on Job Satisfaction among Public Secondary Schools in Arusha District, Tanzania
}

\author{
Goodluck Nzowa \\ School of Education, University of Arusha, Tanzania \\ "Corresponding author: gnzowas@gmail.com
}

\begin{abstract}
This study assessed the effect of teachers' nonmonetary motivational factors on job satisfaction among public secondary schools in Arusha District. Data was collected from a sample of 175 teachers who were randomly selected from 6 public secondary schools. Analysis of data was performed through the SPSS by means of descriptive statistics and hypothesis testing. The findings showed that recognition, promotion, career and professional growth as well as working conditions influenced motivation among public secondary school teachers in Arusha District. On the basis of the findings, it was concluded that non-monetary factors such as recognition, promotion, career and professional growth as well as working conditions play a significant contribution towards motivation and job satisfaction among public secondary school teachers in Arusha District. The study recommends that the government and school management should collaborate to ensure teachers' motivation for quality education provision.
\end{abstract}

Key words: Teachers' motivation, non-monetary factors, job satisfaction, recognition

\section{Introduction}

Job satisfaction is the combination of emotional and psychological factors of employee's experiences at work. It expresses the relationship between expectations and actual achievements. Job satisfaction is also an emotional state resulting from a person's appreciation of his/her own job or experience levels (Demirtas, 2010; Nigama et al, 2018). Job satisfaction is influenced by motivational factors available at work which are in the form of monetary and non-monetary. Specifically, nonmonetary are intrinsic motivational factors that promote employees' excellent job performance. The non-monetary incentives further include pleasant work environment, flexible work hours, training, new and challenging opportunities as well as such factors like free telephone calls, free fuel and fringe benefits such as leave, extra days off for excellent employees, pension, free lunch, and health insurance (Niwamanya,2016; Imbahal, 2016).

In the context of education, teachers' motivation and job satisfaction are essentials for the growth and sustainability of the teaching and learning processes. Motivation can influence both effective performance and job satisfaction among teachers (Kimutai, Kiptum \& Chege, 2016; Mangaleswarasharma, 2017). Benrazavi (2013) also argues that any work cannot be effectively done without satisfaction. Therefore, teachers would get interested to teach their students effectively when they are satisfied with their jobs. According to Hoy and Miskel (2013), teachers' job satisfaction can be enhanced by self-developmental opportunities, short term courses, seminars, workshops, high appreciation and rewards for commendable work.

Teachers' motivation is a global agenda. United Nations Educational, Scientific and Cultural Organization (UNESCO) and International Labour Organization (ILO) emphasize on teachers' motivation for delivery of quality education. Teachers should be motivated through adequate salaries, provision of bonuses and pleasant work environments with sufficient teaching facilities (UNESCO \& ILO, 2012). Teachers are central to achievement of the current global agenda of 2030 Sustainable Development Goals (SDGs). They are 
also important for achieving the SDG 4 which is formulated to 'Ensure inclusive and quality education for all and to promote lifelong learning (UNESCO-IICBA, 2017).

Despite the importance of motivation, teachers working in African countries are de-motivated by unpleasant working environments and low salaries (Bennell \& Akyeampong, 2007). The problem of demotivation has resulted into low teachers' commitment, teachers' strikes, poor instructional preparation, underutilization of teaching time and job dissatisfaction (Muvunyi, 2016). In the context of Tanzania, studies have shown the prevalence of the problem of de-motivation among teachers working in government secondary schools. The challenge prevails in low pay, inadequate teaching facilities or poor school leadership (Bennel \& Mukyanuzi, 2005; Mkumbo, 2011; Kalega, 2016; Nyamubi, 2017). As a result teachers working in government schools are dissatisfied with their jobs.

Globally, much has been investigated about teachers' motivational factors and job satisfaction. For instance, a study on job satisfaction among school teachers in India by Nigama, et al, (2018) confirmed that teacher's relationship with the administration and working environment were the factors that affected their job satisfaction. The findings further indicated that factors that motivated teachers were the same that made them satisfied in their teaching profession. In Pakistan, the study by Sahito and Vaisanen (2017) revealed that factors of job satisfaction were found to be salary, career prospects, supervision, management, working environment and culture. The study further proved and accepted that highly motivated staff were satisfied and performed their jobs better than poorly motivated ones. This gives an expression that there is a potential existence of the relationship between teachers' motivational factors and job satisfaction.

Different researchers in Africa have investigated the teachers' motivational factors on job satisfaction. For instance, a study on analysis of teacher's motivation on the overall performance of public basic schools in Ghana by Shafiwu and Salakpi (2013) indicated that working conditions, the workload, availability of opportunities for professional upgrading, promotion and the existence of community support and recognition were the factors for teachers towards their job satisfaction and performance. Similarly, a study carried out in Zimbabwe on job satisfaction levels and motivation among teachers by Nhunta and Nhuta (2017) reported that a variety of factors such as salary, job security, physical conditions, promotion, recognition and others, do influence teachers' job satisfaction. Therefore, where there is poor motivation, teachers are usually dissatisfied (Kimutai, Kiptum \& Chege, 2016).

In Tanzania, a number of studies have been conducted on motivational factors that can amplify teachers' job satisfaction. For instance, Mark (2015) while examining the factors influencing teachers' motivation and job performance in Kibaha District, the study found that teachers' motivation is influenced by job security, pleasant working conditions, recognition of the best performance, respecting the teaching profession, good pay, fringe benefits, available training opportunity, good interpersonal relationship and available promotion opportunities. Another study by Mkumbo (2016) analyzed job satisfaction and motivation of primary school teachers in Tanzania and found out that teachers who were motivated through nonmonetary factors such as housing, interpersonal relationships with fellow teachers, administrators and students as well as job security were more satisfied in their job than those who were not. Similarly, a study on motivation and job satisfaction among secondary school teachers in Kinondoni Municipality by Shenyagwa (2014) revealed that teachers in public secondary schools were satisfied with their job because of some motivating factors such as recognition from their supervisors, health and safety schemes, protection schemes, employment security as well as training and development. The study further postulated that some teachers were satisfied and motivated as their employers managed to recognize their presence and roles through the provision of various fringe benefits.

Although the studies by Shenyagwa (2014), Mark (2015) and Mkumbo (2016) have largely contributed to the understanding of teacher's motivational factors on job satisfaction, they focused on teachers' monetary motivational factors for job satisfaction. This reveals a gap in the literature which motivated the need to analyze nonmonetary motivational factors that influence job satisfaction among teachers in the context of Tanzania. Therefore, this study analyzed the nonmonetary motivational factors that influence job satisfaction 
among teachers working in public secondary schools in Arusha District. The study was guided by the following three research questions.

1. What are the teachers' nonmonetary motivational factors in public secondary schools in Arusha District?

2. What is the level of teachers' motivation in public secondary schools in Arusha District?

3. Is there any significant relationship between teachers' nonmonetary motivational factors and teachers' job satisfaction among public secondary schools in Arusha District?

\section{Related Literature and Studies}

This part presents both the theoretical and the empirical literature review that informed the author in the process of writing.

\section{Theoretical Framework}

The study was guided by two-factor theory of motivation which was propagated by Hertzberg (1959). The theory states that there are two factors that an organization can adjust to influence motivation in the workplace. The theory looked at motivators and hygiene factors and proposed that job satisfaction and dissatisfaction appeared to be caused by two sets of different factors. Herzberg constructed a two-dimensional paradigm of factors affecting people's attitudes about work. After conducting a massive study, he developed a 'Two Factor Theory' that identifies two sets of factors contributing to motivation, job satisfaction and dissatisfaction. These are: hygiene factors which include salary, relation with superiors and peers, quality of technical supervision, company policy and administration, working condition and other factors that include achievements, recognition, work itself, responsibility, advancement and possibility of growth (Jerome, 2013).

Young (2017) argues that motivating factors are intrinsic and related to non-monetary. They promote a sense of achievement among employees by making employees feel proud of their accomplishments. In schools, teachers need to be given that sense of achievement so that they are satisfied with their job. The second is recognition whereby the job must provide an employee with praise and recognition of their successes. This recognition should come from both the superiors and peers. When teachers are recognized, they feel valued hence become motivated.
On the other hand, poor hygiene factors decrease employees' job satisfaction. According to Bušatlić and Mujabašić (2018), inappropriate extrinsic or hygiene factors cause employees to be unhappy with their job. They include company policies whereby the policies should be fair and clear to every employee. Furthermore, there should be sound relationships between peers, superiors and subordinates. Working areas should be safe, fit for purpose and hygienic. Further, the pay structure (salary) should be fair and reasonable. It should also be competitive with other schools such as private schools in the same educational sector. Therefore, Herzberg Two Factor Theory was suitable in explaining the teachers' nonmonetary motivational factors on job satisfaction among public secondary schools in Arusha District.

\section{Empirical Literature Review}

Nonmonetary motivational factors have been observed to be more effective than the monetary motivational factors towards teacher's job satisfaction. This is supported by studies conducted in various countries in the world.

Outside Africa, various studies have shown the influence of non-monetary factors on teachers' job satisfaction. A study by Ystad (2018) on the promotion of the status and quality of teachers in the United Kingdom revealed that teacher motivation and satisfaction are inextricably linked as one influences the other. The study further indicated that despite the significance of salaries for teachers, nonmonetary factors such as promotion have proven to be more effective in making teachers satisfied. Another study done in Romania on teachers' satisfaction with life, job satisfaction and their emotional intelligence by Ignat and Clipa (2011) revealed that teachers who are motivated feel they live a meaningful life and they share goals and values which are important for them. They mentioned nonmonetary motivational factors like recognition, promotions and career development as key issues towards a high level of motivation among teachers.

In the context Africa, various studies have shown the link between non-monetary factors and job satisfaction. For instance, Niwamanya (2016) studied the effects of financial and non-financial motivation on performance of teachers in Uganda and found that recognition and reward programs are important to keep high spirit and boost up performance and motivation of teachers. 
Furthermore, the findings from a study done in North West Nigeria about teachers' motivation and job satisfaction by Nwakasi and Cummins (2018) affirmed that factors like normal class size, effective administrative supervision, government support, presence of teaching incentives, adequate teaching materials and sound teaching conditions enhanced teachers job satisfaction.

In Kenya, a study by King'oo (2016) analyzed the factors that influence job satisfaction among teachers. The study found that despite the low pay, nonmonetary factors such as normal load, normal class size, school environment, school rules, educational policies and adequate resources motivated teachers and led to job satisfaction. The findings complement with those by Gatsinzi, Jesse and Makewa (2014) whose study on work and school related variables in teacher motivation in Rwanda revealed that motivation of public primary school teachers in Gasabo District is due to work supervision, responsibility assignment and how teacher effort is acknowledged and respected.

In the context of Tanzania, studies have also shown the influence of non-monetary factors on job satisfaction. For example, Mark (2015) when examining the factors influencing teachers' motivation and job performance in Kibaha District found that career and professional growth among teachers motivated them as they were able to add new skills, develop their experience and cope with the changing world. The findings further revealed that the nonmonetary motivational factors not only influenced job performance but also job satisfaction. While the study by Mark (2015) focused on Kibaha District, its findings are no satisfactory to provide understanding about other districts in Tanzania such as Arusha. Therefore this study has covered the gap by analyzing the effects of nonmonetary factors on job satisfaction among public secondary school teachers in Arusha District.

\section{Research Methodology}

The study employed quantitative research approach. According to Creswell (2014) quantitative research is the processes of collecting, analyzing, interpreting and reporting the results of a study using statistical methods. Quantitative approach includes designs such as survey and experimental which can be used for testing objective theories by examining relationships among variables.

\section{Research Design}

This study employed the survey research design. Survey design is one that is used when a researcher seeks to describe attitudes of a population by studying a sample of that population (Akhtar, 2016). The researcher used the survey research design because the study had large number of respondents. Also the design was useful as it helped the researcher to collect a broad range of data regarding the attitudes and opinions of Arusha District teachers toward the problem under investigation.

\section{Population and Sampling}

The population of the study refers to the group of people to which a researcher wants to generalize the results of the study. The population may involve a larger group of people, institution or things that have one or more characteristics in common on which a study focuses. It consists of all cases of individuals or elements that fit a certain specification (Debois, 2018). In this study, the targeted population was the teachers from selected secondary schools in Arusha District with the population of 320 from whom the sample of 175 respondents was randomly selected through systematic sampling procedures.

\section{Data Collection}

The study used a questionnaires to collect primary data.. According to Debois (2018), questionnaires are practical and cover a large number of respondents compared to other methods like interviews. The information generated from the questionnaires can be verified and cross-checked against the information collected using other data collection techniques. Questionnaires are generally less expensive and do not consume a lot of time in the administration. In this study, the questionnaire techniques enabled the researcher to reach all groups included in the study at the same time thus, the collection of data was easy and cheap. The closed-ended items were prepared in the questionnaires with four options for respondents to indicate their level of agreement or disagreement as follows: $1=$ Strongly Disagree, $2=$ Disagree, 3= Agree and 4 = Strongly Agree.

\section{Validity and Reliability}

Reliability is the degree to which a test is consistent and stable in measuring whatever it is measuring. The researcher conducted a pilot study to check the reliability questionnaire. Before the pilot study took place, three experts in research went through the 
questionnaire and gave comments to ensure that the content is well understood and matches with research questions that guided the study. The data was tested through SPSS to ensure the internal consistency. As reflected in Table 1, the test yielded Cronbach's Alpha of .888 for Nonmonetary factors, .863 for recognition, .856 for promotion, .929 for career development, .914 for working conditions and .951 for job satisfaction.

Table 1: Reliability Test Results

\begin{tabular}{llcc}
\hline SN & Variable & Item & Cronbach's Alpa \\
\hline 2 & Recognition & 8 & 863 \\
3 & Promotion & 6 & .856 \\
4 & Career Dev. & 6 & .929 \\
5 & Working Condition & 8 & .914 \\
6 & Job Satisfaction & 20 & .950 \\
\hline
\end{tabular}

\section{Data Analysis Plan}

Data were collected, coded and then entered in SPSS whereby frequency and percentage were used to analyze the demographic characteristics of respondents and descriptive statistics such as mean and standard deviation were used to analyze data for the first and second research questions. Interpretation of mean score was as follows: 3.5-
$4.00=$ strongly agree, 2.5-3.49=agree, 1.5-2.49= disagree and 1.00-1.49= strongly disagree.

Pearson correlation was used to analyze data for the third research question which sought to establish the relationship between teachers' nonmonetary motivational factors and job satisfaction in public secondary schools in Arusha District.

\section{Analysis and Results}

This part presents analysis and results which was guided by three research questions.

RQ1: What are the teachers' nonmonetary motivational factors in public secondary schools in Arusha District?

The findings for this question are summarized in Table 2 where the highest scored non-monetary factor was recognition ( $M=3.04, S . D=1.07369)$. The second non-monetary factor was career and professional growth ( $M=2.97, S . D=.95680)$ while the third was working condition $(M=2.77, S . D=1.06253)$ and the last one was promotion $(M=2.74$, $S . D=1.18878)$. These findings entail that respondents agreed that recognition, career and professional growth, working condition and promotion were important non-monetary factors to motivate teachers.

Table 2 teachers' nonmonetary motivational factors teachers' job satisfaction

\begin{tabular}{llccl}
\hline SN & \multicolumn{1}{c}{ Item } & Mean & Std. Dev & Interpretation \\
\hline 1. & Recognition & 3.04 & 1.07369 & Agree \\
2. & Career And Professional Growth & 2.97 & .95680 & Agree \\
3. & Working Condition & 2.77 & 1.06253 & Agree \\
4. & Promotion & 2.74 & 1.18878 & Agree \\
\hline
\end{tabular}

Table 3: Perception of Teachers on Recognition Factor

\begin{tabular}{llccc}
\hline SN & \multicolumn{1}{c}{ Item } & Mean & Std. Dev & Interpretation \\
\hline 1. & My students see me as their mentor & 3.37 & .67531 & Agree \\
2. & My head of school treats me well & 3.21 & .73443 & Agree \\
3. I receive recognition from my immediate supervisor & 3.04 & .78411 & Agree \\
4. $\quad$ My opinions and ideas are valued and recognized & 3.04 & .82182 & Agree \\
5. I have the freedom to make my own decisions & 2.93 & .87923 & Agree \\
6. $\quad$ My rights as a teacher are well respected & 2.89 & .90713 & Agree \\
\hline
\end{tabular}

These findings are in agreement with those by Cheema, Shujaat and Alam (2013) on the impact of nonmonetary rewards on employees' motivation which mentioned working conditions, career and professional growth, promotion and recognition as important nonmonetary rewards that motivated employees.
RQ 2: What is the level of teachers' motivation among public secondary schools in Arusha District?"

The findings for recognition factors are presented in Table 3 which shows that the mean score for each item was between 2.50 and 3.49 denoting that respondents agreed that their students considered them as their mentors, the heads of schools treat them well, they receive recognition from their 
immediate supervisors, their opinions and ideas are valued and recognized, they have freedom to make their own decisions and that their rights as teachers are well respected.

The second variable for nonmonetary factors for teachers' motivation factor was promotion. Respondents indicated their perception toward six items in the questionnaire as shown in Table 4. The table shows that respondents agreed on only two items; supervisor's recommendation for promotion $(\mathrm{M}=2.89, \mathrm{SD}=.82575)$ and awareness of promotion criteria ( $M=2.85, S D=.85082)$. However, they disagreed with involvement in promotion process
$(M=2.30, S D=.99333)$, fairness in promotion $(\mathrm{M}=2.25, \mathrm{SD}=.98648)$ and getting promotion on the right time $(M=2.00, S D=0.98726)$. These findings imply that promotion is a motivational factor in terms of supervisor recommendation and teachers' awareness. These findings imply a need to improve on those motivational factors which were disagreed upon by teachers.

The third variable was career and professional growth. The findings for this variable are shown in Table 5.

Table 4: Perception of Teachers on Promotion Factor

\begin{tabular}{llccc}
\hline SN & \multicolumn{1}{c}{ Item } & Mean & Std. Dev & Interpretation \\
\hline 1. & My supervisor recommends me well for promotional & 2.89 & 82575 & Agree \\
2. & I'm aware of the promotion criteria & 2.85 & .85082 & Agree \\
3. & Promotional procedures are open & 2.35 & .98718 & Disagree \\
4. I'm involved in the process of promotion & 2.30 & .99333 & Disagree \\
5. & There is fairness in promotion & 2.25 & .98648 & Disagree \\
6. & I get promoted at the right time & 2.00 & .98726 & Disagree \\
\hline
\end{tabular}

Table 5: Perception of Teachers on Career and Professional growth

\begin{tabular}{llccc}
\hline SN & \multicolumn{1}{c}{ Item } & Mean & Std. Dev & Interpretation \\
\hline 1. I'm aware of the procedures for career and professional & 3.01 & .85751 & Agree \\
$\quad \begin{array}{l}\text { growth } \\
\text { 2. I get good recommendation from my supervisor for career }\end{array}$ & 2.94 & .90728 & Agree \\
$\quad \begin{array}{l}\text { and professional growth } \\
\text { 3. My supervisor encourages me in advancing professionally }\end{array}$ & 2.79 & .97230 & Agree \\
4. I get opportunity to advance professionally & 2.73 & 1.00583 & Agree \\
5. There is fair opportunities for career and professional growth & 2.72 & .97516 & Agree \\
6. I get support for career and professional development & 2.68 & .99262 & Agree \\
\hline
\end{tabular}

Table 6: Perception of Teachers on Working Condition

\begin{tabular}{llccc}
\hline SN & \multicolumn{1}{c}{ Item } & Mean & Std. Dev & Interpretation \\
\hline 1. & My immediate supervisor gives me assistance when I need help & 3.14 & .72116 & Agree \\
2. & There is good communication between seniors and low level workers & 3.06 & .79509 & Agree \\
3. & The performance appraisal is fair & 2.97 & .73968 & Agree \\
4. & My supervisor makes available material I need to do my best. & 2.94 & .84042 & Agree \\
5. & My teaching load is normal & 2.87 & .93958 & Agree \\
6. & Working conditions in my school are comfortable & 2.79 & .96177 & Agree \\
7 & I have a good office to perform my duties & 2.77 & 1.00713 & Agree \\
8 & The school has good sanitation facilities for teachers & 2.72 & 1.02914 & Agree \\
\hline
\end{tabular}

The table shows that respondents agreed that they are aware on procedures for career and professional growth $(\mathrm{M}=3.01, \mathrm{SD}=.85751)$, supervisors provide good recommendation for career and professional growth $(\mathrm{M}=2.94, \mathrm{SD}=.90728)$, supervisors encourage professional advancement $(M=2.79$, S.D=.97230), opportunity for professional advancement $(M=2.73, S . D=1.00583)$, opportunities for career and professional growth $(M=2.72, S . D=$
.97516) and support for career and professional development ( $M=2.68, S . D=.99262)$.

The fourth variable was working conditions as reflected in Table 6.

The table indicates that immediate assistance by supervisor was the highest factor $(M=3.14, S . D=$ .72116), followed by good communication between seniors and low level workers (M=3.06, S.D= 
.79509). The next factor was fairness of performance appraisal $(M=2.97, S . D=.73968)$, followed by availability of teaching materials $(\mathrm{M}=2.94$, $\mathrm{S} . \mathrm{D}=.84042)$. The next ranked was teaching load $(M=2.87, S . D=.93958)$ which was followed by comfortable working conditions $(M=2.79, S D=.96177)$. The next was good office for performing duties $(M=2.77, S . D=1.00713)$ while the last ranked factor was good sanitation facilities for teachers $(M=2.72, S . D=1.02914)$.

Findings for the second research question have shown that working conditions, career development and promotions were the most cited regarding the level of teachers' motivation. These findings are Similar with those findings by Gatsinzi, Jesse and Makewa (2014) in their study on work and school related variables in teacher motivation in Rwanda, which mentioned recognition, career development, working conditions and promotion as among the intrinsic motivational factors.

RQ 3: Is there significant relationship between teachers' nonmonetary motivational factors and job satisfaction among public secondary schools in Arusha District?
Findings for this question are shown in Table 7 which indicates that there is a strong positive relationship between recognition and job satisfaction $(p=.00, r=.688)$ as well as between working condition and job satisfaction $(p=.00$, $r=.697$. The table further indicated that there is moderate positive relationship between career and professional growth and job satisfaction $(p=.00$, $r=.578$. This means that recognition, working conditions as well as career and professional growth influenced teachers' job satisfaction. Furthermore, there is a weak yet positive correlation between promotion and teachers' job satisfaction $(p=.00$, $r=.431$ ), and between promotion and recognition $(p=.00, r=.446)$. This suggests that promotion slightly influenced teachers' job satisfaction. Therefore, there is need to improve promotion procedures for teachers to be more satisfied with their job. Generally, findings have revealed the existence of significant relationship between nonmonetary motivational factors and job satisfaction among public secondary schools in Arusha District.

Table 7: Correlation between Independent and Dependent Variables

\begin{tabular}{|c|c|c|c|c|c|c|}
\hline & & RECOGNITION & PROMOTION & CAREER & W.CONDIT & SATISFACTION \\
\hline \multirow[t]{3}{*}{ RECOGNITION } & $\begin{array}{l}\text { Pearson } \\
\text { Correlation }\end{array}$ & 1 & $.446^{* *}$ & $.626^{* *}$ & $.715^{* *}$ & $.688^{* *}$ \\
\hline & Sig. (2-tailed) & & .000 & .000 & .000 & .000 \\
\hline & $\mathrm{N}$ & 159 & 159 & 158 & 159 & 159 \\
\hline \multirow[t]{3}{*}{ PROMOTION } & $\begin{array}{l}\text { Pearson } \\
\text { Correlation }\end{array}$ & $.446^{* *}$ & 1 & $.702^{* *}$ & $.537^{* *}$ & $.431^{* *}$ \\
\hline & Sig. (2-tailed) & .000 & & .000 & .000 & .000 \\
\hline & $\mathrm{N}$ & 159 & 159 & 158 & 159 & 159 \\
\hline \multirow[t]{3}{*}{ CAREER } & $\begin{array}{l}\text { Pearson } \\
\text { Correlation }\end{array}$ & $.626^{* *}$ & $.702^{* *}$ & 1 & $.683^{* *}$ & $.578^{* *}$ \\
\hline & Sig. (2-tailed) & .000 & .000 & & .000 & .000 \\
\hline & $\mathrm{N}$ & 158 & 158 & 158 & 158 & 158 \\
\hline \multirow[t]{3}{*}{ W.CONDITION } & $\begin{array}{l}\text { Pearson } \\
\text { Correlation }\end{array}$ & $.715^{* *}$ & $.537^{* *}$ & $.683^{* *}$ & 1 & $.697^{* *}$ \\
\hline & Sig. (2-tailed) & .000 & .000 & .000 & & .000 \\
\hline & $\mathrm{N}$ & 159 & 159 & 158 & 159 & 159 \\
\hline \multirow[t]{3}{*}{ SATISFACTION } & $\begin{array}{l}\text { Pearson } \\
\text { Correlation }\end{array}$ & $.688^{* *}$ & $.431^{* *}$ & $.578^{* *}$ & $.697^{* *}$ & 1 \\
\hline & Sig. (2-tailed) & .000 & .000 & .000 & .000 & \\
\hline & $\mathrm{N}$ & 159 & 159 & 158 & 159 & 159 \\
\hline
\end{tabular}

**. Correlation is significant at the 0.01 level (2-tailed).

Findings for the third research question have shown that there is a positive relationship between recognition and job satisfaction as well as between working condition and job satisfaction. These findings are similar to those by Nyamubi (2017) who

also revealed that teachers' job satisfaction is influence by working conditions and recognition.

\section{Conclusions}

On the basis of the findings, three conclusions are drawn. First of all non-monetary factors under 
investigation, such as recognition, career and professional growth, working conditions and promotions have a significance influence on job satisfaction among government secondary school teachers in Arusha District.

Secondly, it is concluded that recognition, working conditions and career development were the most cited factors for motivating teachers in public secondary schools in Arusha District although, there was problem in promotion procedures for teachers in secondary schools in Arusha District.

Thirdly, this study concludes that motivational factors such recognition working conditions and professional growth have significant relationship with teacher's job satisfaction among public secondary school teachers in Arusha District.

\section{Recommendations}

From the study findings, the following recommendations were made; The government should work out to increase the nonmonetary motivation to the public secondary school teachers. Special attention should be put in making sure that teachers are recognized for their efforts. The teachers also need to be promoted, and given opportunities for career and professional growth. There is also a need improving the working conditions for teachers.

It is also recommended that the government through the Teachers Service Commission (TSC) should review teachers' promotion policies to suit the needs that enhance motivation. The Commission should come up with strategies to reduce the delays in promotion and ensure that qualified teachers are promoted on time.

\section{Reference}

Akhtar, I. (2017, August 18). Research Design. Retrieved from papers.ssrn.com: https://papers.ssrn.com/sol3/papers.cfm?a bstract_id=2862445

Bennel, P., \& Mukyanuzi, F. (2005). Is There a Teacher Motivation Crisis in Tanzania? London: Eldis.

Bennell, P., \& Akyeampong, K. (2007). Teacher Motivation in Sub-Saharan Africa and South
Asia. London: Department of International Education.

Benrazavi, B. (2013). Employees' Job satisfaction and its influence on willingness to work in terms. Journal of Management Policy and Practice, 14 (1), 127-140.

Bušatlić , S., \& Mujabašić, A. (2018). Herzberg's twofactor theory of job satisfaction. Comparative study between private and public high school teachers in Canton Sarajevo. International Journal of Business Management \& Research, 8 (6), 27-48.

Cheema, F., Shujaat , E., \& Alam, R. (2013). Impact of Non-monetary rewards on employees' motivation. A Study of commercial banks in Karachi. Journal of Management and Social Sciences, 9(2), 23-33.

Creswell, J. W. (2014). Research Design: Qualitative, Quantitative, and Mixed Method Approaches. New York: Sage Publications.

Debois, S. (2019, March 8). 10 Advantages and Disadvantages of Questionnaires. Retrieved from surveyanyplace.com: https://surveyanyplace.com

Demirtas, Z. (2010). Teachers' job satisfaction levels. Procedia-Social and Behavioral Sciences, 9, 1069-1073.

Gatsinzi, P., Jesse, R., \& Makewa, M. N. (2014). Work and School Related Variaables in Teacher Motivation in Gasabo District, Rwanda. Journal of Education and Training, 1(2), 262-273.

Hoy, W. K., \& Miskel, C. G. (2013). Educational Administration. New York: McGriaw-Hill Companies, Inc.

Ignat, A. A., \& Clipa, O. (2011). Teachers' satisfaction with life, job satisfation and their emotional intelligence. Procedia-Social and Behavioral Sciences, 33, 498-502. 
Imbahale, N. I. (2016). Effecrs of Non-Monetary Rewards towards Employee Motivation. Master Thesis. Dar es Salaam: The Open University of Tanzania.

Jerome, N. (2013). Application of the Maslow's hierarcy of needs theory: Impacts and implications on organizational culture, human resource and employee's performace. Journal of Business and Management Invention, 2(3), 39-45.

Kalage, R. (2016). Teachers Motivation and Job Satisfaction Research Report. Dar es Salaam: HakiElimu.

Kimutai, T. S., Kiptum, K. G., \& Chege, K. (2016). Role of Non-monetary reward management practices on teachers' retention in public primary schools. A survey of Turkana East sub county, Kenya. Journal of Business and Management, 18 (11), 39-51.

King'oo, N. M. (2016). School Factors Influencing Job Satisfaction Among Teachers. A Case of Machakos Town, Sub Couny, Kenya. Master Thesis. Nairobi: University of Nairobi.

Mangaleswarasharma, R. (2017). Teacher motivation and job satisfaction. A Study on Teachers in three Districts in Northern Sir Lanka. International Journal of Social Sciences, 3, 314-323.

Mark, A. (2015). Factors Influencing Teachers' Motivation and Job Performance in Kibaha District, Tanzania. Master Thesis. Dar es Salaam: The Open University of Tanzania.

Mkumbo, K. (2011). Are our Teacher Qualified and Motivated to Teach? A research report on Teachers' qualifications. Motivation and commitment to Teach and their implications on Quality Education. Dar es Salaam: HakiElimu.

Mkumbo, K. (2016). Job Satisfaction and Motivation of Primary School Teachers in Tanzania. Dar es Salaam: University of Dar es Salaam.
Muvunyi, E. (2016). Teacher Motivation and Incentives in Rwanda: Analysis of Stakeholders' Perceptions of the Changes in Teachers' Motivation During 2008-13. Ph.D. thesis. Brighton, England: University of Sussex.

Nhunta, S., \& Nhuta, P. (2017). Job satisfaction levels and motivation among teachers. A Comparative analysis of teachers in government public and private schools. Journal of Educational Policy and Entrepreneurial Research, 4(1), 36-60.

Nigama, K., Selvabaskar, S., Surulivel, S. T., Alamelu, R., \& Joice, D. U. (2018). Job satisfaction among school teachers. International Journal of Pure and Applied Mathematics, 119(7), 2645-2655.

Niwamanya, J. (2016). Effect of Financial and Nonfinancial Motivation on Performance Teachers in Private Secondary Schools in Sheema District, Uganda. Master Thesis. Kampala: Uganda Technology and Management University.

Nwakasi, C. C., \& Cummins, P. A. (2018). Teacher motivatin and job satisfaction. A case study of North West Nigeria. Global Journal of Education Research,17, 103-112.

Nyamubi, G. J. (2017). Determinants of Secondary School Teachers' Job Satisfaction in Tanzania. Education Research International, 1-7.

Sahito, Z., \& Vaisanen, P. (2017). Factors affecting job satisfaction of teacher educators. Emperical evidence from the Universities of Sindh Province of Pakistan. Journal of Teacher Education and Educators, 1, 5-30.

Shafiwu, A. B., \& Salakpi, A. (2013). Analysis of teachers motivation on the overall performance of public basic school in Wa Municipality. Research Journal of Finance and Accounting, 4 (13), 179-194. 
Shenyagwa, L. (2014). Assessment on Motivation and Job Satisfaction Among Secondary School Teachers in Tanzania with Reference to Selected Public and Private Secondary Schools in Kinondoni Muncipalty in Dar es Salaam. Master Thesis. Morogoro: Mzumbe University.

UNESCO and ILO. (2012). Joint ILO-UNESCO Committee of Experts on the Application of the Recommendations. Geneva: International Labour Office.
UNESCO-IICBA. (2017). Teachers' Support and Motivation Framework for Africa: Emerging Patterns. Addis Ababa: UNESCO-IICBA.

Young, J. (2017, November 29). Heroes of Employee Engagement: No.3 Frederick Herzberg's Two Factor Theory. Retrieved from peakon.com: https://peakon.com

Ystad, S. (2018, June 26). Promotion of the status and quality of teachers. Retrieved from www.regjeringen.no:

https://www.regjeringen.no 